\title{
Impact of heat stress, nutritional stress and combined (heat and nutritional) stresses on rumen associated fermentation characteristics, histopathology and HSP70 gene expression in goats
}

\author{
Kunnath Chaidanya - Nira Manik Soren - Veerasamy Sejian • \\ Madiajagan Bagath - Gundallahalli Bayyappa Manjunathareddy • \\ Echacadu Kurien Kurien - GirishVarma - Raghavendra Bhatta
}

K Chaidanya ${ }^{1,2}$ - NM Soren ${ }^{1}$ - V Sejian ${ }^{1}$ (Corresponding author) - M Bagath ${ }^{1}$ - EK Kurien ${ }^{2}$ - R Bhatta ${ }^{1}$

${ }^{1}$ ICAR-National Institute of Animal Nutrition and Physiology, Adugodi, Bangalore, India.

${ }^{2}$ Academy of Climate Change Education and Research, Kerala Agricultural University, Vellanikkara, Thrissur, Kerala, India.

email: drsejian@gmail.com

\section{GB Manjunathareddy}

ICAR-National Institute of Veterinary Epidemiology and Disease Informatics, Yelahanka, Bangalore-560064, India.

\section{G Varma}

Centre for Animal Adaptation to Environment and Climate Change Studies, Kerala Veterinary and Animal Sciences University, Mannuthy, Thrissur, Kerala, India.

Received: November 12, 2016 • Accepted: January 26, 2017

\begin{abstract}
A study was conducted to assess the impact of heat stress, nutritional stress and combined stresses (heat and nutritional stress) on rumen fermentation characteristics, histopathology of rumen and rumen HSP70 gene expression in goats. Twenty four adult Osmanabadi bucks were divided into four groups, $\mathrm{C}$ ( $\mathrm{n}=6$; control), HS ( $\mathrm{n}=6$; heat stress), NS ( $\mathrm{n}=6$; nutritional stress) and CS ( $\mathrm{n}=6$; combined stress). The study was conducted for a period of 45 days. The $\mathrm{C}$ and HS bucks had ad libitum access to their feed while NS and CS bucks were subjected to restricted feed (30\% intake of C bucks) to induce nutritional stress. The HS and CS bucks were exposed to heat stress in an outside environment. Both feed intake and body weight were significantly $(\mathrm{p}<0.01)$ lower in CS and NS groups. The carboxy methyl cellulase activities - extracellular, intracellular and total activity in the rumen fluid differed significantly $(\mathrm{p}<0.01)$ between the groups. The highest concentration of ammonia nitrogen $(\mathrm{p}<$ 0.05) was recorded in $\mathrm{C}$ while the lowest in the CS group. The concentration of total nitrogen and trichloroacetic acid precipitable $\mathrm{N}$, propionic acid, butyric acid, and valeric acid was lower $(\mathrm{p}<0.01)$ in the restricted fed (NS and CS) bucks as compared to ad libitum fed groups (C and HS). Further, the ratio of acetate to propionate (A:P ratio) was also significantly $(p<0.01)$ higher in CS and NS groups. The higher expression of rumen heat shock protein 70 (HSP70) mRNA was observed in CS goats. The histopathological section of rumen revealed a reduction in the length of rumen villi and thickness in CS, whereas rumen keratinization was highest in the CS group. From the study it can be concluded that when two stresses occur simultaneously, they may have severe impact on rumen fermentation characteristics of bucks.
\end{abstract}

Keywords: buck, combined stress, fermentation, heat stress, HSP70, nutritional stress, rumen, VFAs

\section{Introduction}

Globally, agriculture provides livelihood for more people than the industries (Upton 2004). Livestock contributes 40 per cent of the global value of agricultural output and support the livelihoods and food security of almost a 1.3 billion people (Herrero et al 2013). The livestock sector is one of the fastest growing sectors of the agricultural economy. The growth and transformation of the sector provide opportunities for agricultural development, poverty reduction and food security gains.

The goat is an important source of milk, meat and fiber for the people throughout the world. They are found in many climatic regions of the world, ranging from the arctic cold, temperate, deserts and mountains to subtropical and tropical dry and humid zones. They are recognized as one of the most successful domestic ruminants of the tropics and subtropics, which involve the arid, semi-arid, sub-humid, humid and the super humid climates. In these regions, climatic stresses, limitations of food, water quality and quantity, add challenges to the adaptability of goats in addition to the presence of internal and external parasites. The goats must possess high adaptive capability to be successful in surviving and reproduce in all these environments.

Increased environmental temperature leads to variations in the basic rumen physiology. Heat stress (HS) reduces the total production of volatile fatty acids (VFAs) with individual variation. Passage rate and retention time of digesta is also influenced by a rise in ambient temperature 
and thus affects digestibility. The high ambient temperature also causes various changes in the characteristics and pattern of rumen fermentation, which alters the rumen $\mathrm{pH}$, affects the microbial population and VFAs production in the rumen. The change in rumen microbiota due to HS may alter the fermentation pattern leading to variations in digestibility, VFA production and methane $\left(\mathrm{CH}_{4}\right)$ emission (Yadav et al 2013). Perhaps diet is considered one of the most vital variables affecting microbial fermentation. Further, during the summer months there is a huge reduction in pasture availability leading to severe nutritional stress (NS) to the grazing goats. The type and availability of diet also was found to influence rumen fermentation characteristics in goats (Riaz et al 2014).

Animals reared under hot environment are generally subjected to more than one stress at a time. This seriously hampers the animal production and reproduction under such environmental conditions (Naqvi and Sejian 2010). In tropical countries, these environmental challenges occur simultaneously rather than in isolation and the cumulative impact of these are more severe than the impact when they occur individually. However, there are only few studies available on the effects of combined and multiple stresses on livestock (Sejian et al 2011; Sejian et al 2013). The adverse effects of these cumulative stresses are to be established for developing suitable adaptation strategies to sustain livestock production in the changing climate scenario especially in the tropical regions. Also elucidating the rumen fermentation pattern of the livestock under the influence of multiple climatic factors are important for developing suitable mitigation strategies for reducing the contribution of livestock towards climate change. Hence an attempt has been made in this study to establish the effect of more than one stress simultaneously on the rumen fermentation pattern in goats. The primary objective of the study was to establish the impact of HS and NS individually as well as simultaneously on the rumen associated fermentation characteristics, histopathology as well as HSP70 gene expression in goats.

\section{Materials and Methods}

\section{Location}

The experiment was carried out at the National Institute of Animal Nutrition and Physiology experimental livestock farm, Bengaluru, India, which is located in the southern Deccan plateau of the country at longitude $77^{\circ} 38^{\prime} \mathrm{E}$ and the latitude of $12^{\circ} 58 \mathrm{~N}$ and at altitude of $920 \mathrm{~m}$ above mean sea level. The average annual minimum and maximum ambient temperature ranges between 15 to $36{ }^{\circ} \mathrm{C}$. The mean annual relative humidity (RH) ranges between 20 and $85 \%$. The annual rainfall in this area ranges from 200 to $970 \mathrm{~mm}$ with an erratic distribution throughout the year. The average annual minimum and maximum temperatures were measured using minimum and maximum thermometer and they ranged between 15-22 and $27-34{ }^{\circ} \mathrm{C}$ respectively. The average annual $\mathrm{RH}$ was recorded using hygrometer and it ranged between 40-85\%. The experiment was carried out during April-May. The temperature and $\mathrm{RH}$ variations during the study period (April-May) was recorded using thermohygrometer and they ranged between $24-38{ }^{\circ} \mathrm{C}$ and $30-38 \%$ respectively under hot semi-arid environment. Further, the dry and wet bulb temperatures were recorded using dry and wet bulb thermometer. The average meteorological data for the entire study period both inside the shed as well as outside are given in Table 1 respectively. The temperature humidity index (THI) values were calculated as per method described by McDowell (1972). Accordingly the formula used was THI $=0.72\left(\mathrm{~T}_{\mathrm{db}}+\mathrm{T}_{\mathrm{wb}}\right)+40.6$ where, $\mathrm{T}_{\mathrm{db}}=$ Dry bulb temperature in ${ }^{\circ} \mathrm{C} ; \mathrm{T}_{\mathrm{wb}}=$ Wet bulb temperature in ${ }^{\circ} \mathrm{C}$. The THI values below 70 are considered comfortable and THI values between 75 and 78 are considered stressful and THI above 78 are considered extreme distress.

Animals

Osmanabadi is a dual purpose (meat and milk) hardy goat breed, which originated in the semi-arid areas of central tropical India. The study was conducted in 24 (one year old) Osmanabadi bucks weighing between 15 to $18 \mathrm{~kg}$. The animals were housed in well-ventilated sheds made up of asbestos roofing, open from side and maintained under proper hygienic conditions. Prophylactic measures against goat diseases like goat pox, peste des petits ruminants, enterotoxaemia, endo and ectoparasitic infestations were carried out as prescribed by the health calendar of the institute to ensure that the animals were in healthy condition throughout the study.

\section{Technical details}

The study was conducted for a period of 45 days. Twenty four adult Osmanabadi bucks (average body weight (BW) $16.0 \mathrm{~kg}$ ) were used in the present study. The bucks were divided into four groups, $\mathrm{C}(\mathrm{n}=6$; control), HS ( $\mathrm{n}=6$; heat stress), NS ( $\mathrm{n}=6$; nutritional stress) and CS ( $\mathrm{n}=6$; combined stress). The animals were stall fed individually with a diet consisting of $60 \%$ roughage (Hybrid Napier) and $40 \%$ concentrate (maize $36 \mathrm{~kg}$, wheat bran $37 \mathrm{~kg}$, soya bean meal $25 \mathrm{~kg}$, mineral mixture $1.5 \mathrm{~kg}$ and common salt $0.5 \mathrm{~kg} / 100 \mathrm{~kg}$ of feed). The $\mathrm{C}$ and NS bucks were maintained in the shed where the animals were exposed to a maximum temperature of $35.6{ }^{\circ} \mathrm{C}$ while $\mathrm{HS}$ and CS bucks were exposed outside environment to summer HS between 10:00 h to 16:00 $\mathrm{h}$ where the maximum temperature was $38.3{ }^{\circ} \mathrm{C}$ with the difference of around $3{ }^{\circ} \mathrm{C}$ between inside and outside the 
shed during the study period. The $\mathrm{C}$ and HS group bucks were provided with ad libitum feeding while NS and CS bucks were provided with restricted feed $(30 \%$ of intake of ad libitum) to induce nutritional stress. Table 2 describes the ingredients and chemical composition of the feed offered to the animals. All the animals were fed and watered individually throughout the study period. All cardinal weather parameters were recorded both inside and outside the shed. Rumen liquor was collected at fortnightly interval. The study was conducted after obtaining approval from the institute ethical committee for subjecting the animal to both heat and nutritional stresses and for slaughtering the animals for collection of organs for histopathological section and gene expression studies.

\begin{tabular}{|c|c|c|c|c|c|c|c|}
\hline $\begin{array}{l}\text { Type of } \\
\text { Environment }\end{array}$ & $\begin{array}{l}\text { Time of } \\
\text { Recording }\end{array}$ & $\begin{array}{l}\text { Minimum } \\
\text { temperature } \\
\left({ }^{\circ} \mathrm{C}\right)\end{array}$ & $\begin{array}{c}\text { Maximum } \\
\text { temperature } \\
\left({ }^{\circ} \mathrm{C}\right)\end{array}$ & $\begin{array}{c}\text { Dry bulb } \\
\text { temperature } \\
\left({ }^{\circ} \mathrm{C}\right)\end{array}$ & $\begin{array}{l}\text { Wet bulb } \\
\text { temperature } \\
\left({ }^{\circ} \mathrm{C}\right)\end{array}$ & $\begin{array}{l}\mathrm{RH} \\
(\%)\end{array}$ & THI \\
\hline \multirow[t]{2}{*}{ Inside the Shed } & $\begin{array}{l}\text { Morning } \\
\text { (8:00 hrs) }\end{array}$ & $\begin{array}{l}21.50 \\
\pm 0.60\end{array}$ & $\begin{array}{l}32.37 \\
\pm 0.20\end{array}$ & $\begin{array}{l}23.80 \\
\pm 0.21\end{array}$ & $\begin{array}{l}20.10 \\
\pm 0.17\end{array}$ & $\begin{array}{l}78.67 \\
\pm 4.67\end{array}$ & $\begin{array}{l}72.21 \\
\pm 0.25\end{array}$ \\
\hline & $\begin{array}{l}\text { Afternoon } \\
\text { (14:00 hrs) }\end{array}$ & $\begin{array}{c}24.4 \\
\pm 0.56\end{array}$ & $\begin{array}{l}35.60 \\
\pm 0.72\end{array}$ & $\begin{array}{l}26.47 \\
\pm 0.28\end{array}$ & $\begin{array}{l}20.93 \\
\pm 0.09\end{array}$ & $\begin{array}{l}45.67 \\
\pm 7.21\end{array}$ & $\begin{array}{l}74.73 \\
\pm 0.22\end{array}$ \\
\hline \multirow[t]{2}{*}{ Outside the Shed } & $\begin{array}{l}\text { Morning } \\
\text { (8:00 hrs) }\end{array}$ & $\begin{array}{l}26.93 \\
\pm 2.87\end{array}$ & $\begin{array}{l}34.03 \\
\pm 0.52\end{array}$ & $\begin{array}{l}23.13 \\
\pm 0.20\end{array}$ & $\begin{array}{l}22.97 \\
\pm 0.66\end{array}$ & $\begin{array}{l}61.00 \\
\pm 7.77\end{array}$ & $\begin{array}{l}73.92 \\
\pm 0.57\end{array}$ \\
\hline & $\begin{array}{l}\text { Afternoon } \\
(14: 00 \mathrm{hrs})\end{array}$ & $\begin{array}{l}27.23 \\
\pm 3.46\end{array}$ & $\begin{array}{l}38.33 \\
\pm 0.52\end{array}$ & $\begin{array}{l}29.57 \\
\pm 0.38\end{array}$ & $\begin{array}{l}26.53 \\
\pm 0.71\end{array}$ & $\begin{array}{l}37.00 \\
\pm 4.16\end{array}$ & $\begin{array}{l}80.99 \\
\pm 0.25\end{array}$ \\
\hline
\end{tabular}

SEM-Standard Error Mean; RH- Relative Humidity; THI- Temperature Humidity Index

Rumen fermentation study

Samples of rumen liquor were collected from all the animals at four hours, post feeding by using a stomach tube connected to a hand held pump. The $\mathrm{pH}$ of rumen fluid was determined immediately using a digital $\mathrm{pH}$ meter (Cyberscan pH 512; Eutech Instruments). About $20 \mathrm{ml}$ of rumen fluid was processed for enzyme estimation in sterile centrifuge tubes. The remaining rumen liquor was strained through four layers of cheese cloth. Strained rumen liquor (SRL) $(0.8 \mathrm{ml})$ was mixed in micro centrifuge tubes containing $0.2 \mathrm{ml}$ of $25 \%$ metaphosphoric acid, allowed to stand for 30 minutes at room temperature, centrifuged at $5000 \mathrm{rpm}$ for $20 \mathrm{~min}$, and supernatants were stored for determination of volatile fatty acid (VFA) concentrations at $-20^{\circ} \mathrm{C}$. Saturated mercuric chloride ( $1 \mathrm{ml} / 100 \mathrm{ml}$ of fluid) was added to remaining strained fluid and frozen for analysis of nitrogen fractions.

Table 2 Ingredients and chemical composition of concentrate mixture and hybrid napier hay fed to goats.

\begin{tabular}{|c|c|c|}
\hline Attribute & Concentrate mixture $(\mathrm{kg} / 100 \mathrm{~kg})$ & Napier hay (Pennisetum purpureum) \\
\hline \multicolumn{3}{|l|}{ Ingredients } \\
\hline Maize & 36 & - \\
\hline Wheat bran & 37 & - \\
\hline Soybean meal & 25 & - \\
\hline Mineral mixture & 1.5 & - \\
\hline Salt & 0.5 & - \\
\hline \multicolumn{3}{|l|}{ Chemical composition $(\%)$} \\
\hline Dry matter & $92.9 \pm 0.079$ & $94.0 \pm 0.289$ \\
\hline Organic matter & $95.9 \pm 0.190$ & $95.4 \pm 0.298$ \\
\hline Crude protein & $19.6 \pm 0.176$ & $6.21 \pm 0.098$ \\
\hline Ether extract & $1.82 \pm 0.183$ & $1.49 \pm 0.026$ \\
\hline Total ash & $4.10 \pm 0.190$ & $4.64 \pm 0.298$ \\
\hline \multicolumn{3}{|l|}{ Fibre fractions $(\%)$} \\
\hline Neutral detergent fibre & $40.4 \pm 1.400$ & $82.9 \pm 0.881$ \\
\hline Acid detergent fibre & $11.1 \pm 0.239$ & $64.6 \pm 1.950$ \\
\hline Acid detergent lignin & $2.14 \pm 0.029$ & $12.3 \pm 0.651$ \\
\hline \multicolumn{3}{|l|}{ Nutritive value } \\
\hline Total digestible nutrients $\%^{*}$ & 72.2 & 55.0 \\
\hline Digestible energy $(\mathrm{kJ} / \mathrm{kg})^{*}$ & 13.3 & 10.1 \\
\hline Metabolizable energy $(\mathrm{kJ} / \mathrm{kg})^{*}$ & 10.9 & 8.28 \\
\hline
\end{tabular}

${ }^{*}$ Calculated values 
Analytical procedures

\section{Chemical analysis}

The dry matter by oven drying method (934.01), crude protein by Kjeldahl method (code 984.13), ether extract (920.39) and total ash (code 942.05) in concentrate mixtures and Pennisetum purpureum hay were determined by methods of AOAC (1988). Neutral detergent fiber (NDF) was determined without sodium sulphite or $\alpha$ - amylase and expressed inclusive of residual ash, whereas acid detergent fiber (ADF) was expressed inclusive of residual ash and lignin (sa) was determined by solubilization of cellulose with sulphuric acid as per the procedure of Van Soest et al (1991).

\section{Rumen enzymes assay}

An aliquot $(10 \mathrm{ml})$ of rumen fluid was centrifuged at $14,000 \mathrm{~g}$ for $20 \mathrm{~min}$ at $4{ }^{\circ} \mathrm{C}$ to obtain supernatant for extracellular (EC) enzyme activity and pellet for intracellular (IC) enzyme activity. The crude enzyme solutions from the supernatants and pellets were extracted following the procedure described previously (Agrawal et al 2000). Activities of carboxymethyl cellulase (CMCase), and $\alpha$ amylase were assayed by using the dinitrosalicylic acid (DNS) (Miller 1959). The assay mixture contained $1 \mathrm{ml}$ phosphate buffer, $0.5 \mathrm{ml}$ of sample (enzyme both EC and IC fractions) and $0.5 \mathrm{ml}$ of carboxymethyl cellulose solution $(10 \mathrm{~g} / \mathrm{l})$ with incubation time of $1 \mathrm{~h}$ at $39^{\circ} \mathrm{C}$ for estimation of carboxymethyl cellulose activity and $0.5 \mathrm{ml}$ phosphate buffer, $0.25 \mathrm{ml}$ starch solution $(10 \mathrm{~g} / \mathrm{l})$ and $0.25 \mathrm{ml}$ sample with incubation time of $30 \mathrm{~min}$ at $39^{\circ} \mathrm{C}$ for estimation of $\alpha$ amylase. The amount of reducing sugar (glucose) released was measured colorimetrically (Miller 1959). The enzyme activities were expressed as $\mu \mathrm{mol}$ of reducing sugars released per hour per ml under the assay conditions.

\section{Rumen fermentation metabolites}

The concentration of total nitrogen $(\mathrm{TN})$ and trichloroacetic acid precipitable nitrogen (TCA-ppt N) was determined by Kjeldahl method (AOAC 1988) from $2 \mathrm{ml}$ rumen fluid. For TCA-ppt $\mathrm{N}$ estimation $2 \mathrm{ml}$ of SRL was transferred to a centrifuge tube and $2 \mathrm{ml}$ of $20 \%$ TCA was added and allowed to stand. After 12 hours the tubes were centrifuged at $5000 \mathrm{rpm}$ for $10 \mathrm{~min}$. The precipitate was analysed for TCA-ppt $\mathrm{N}$ by Kjeldahl method using Gerhardt automatic nitrogen analyzer (Model no. KB 20S and VAP 45 $\mathrm{S}$, Gerhardt, Cologne, Germany). Ammonia nitrogen in rumen fluid samples was estimated by spectrophotometric method (Weatherburn 1967).
Volatile fatty acids

The total and individual VFAs content in the rumen fluid samples were determined using gas chromatography (GC) (Agilent; Model 7890A GC System, Shanghai, China) equipped with flame ionization detector (FID), programmable temperature vaporizer injector and capillary column (Agilent J\&W DB-WAX GC Column; length 40 m; internal diameter $0.18 \mathrm{~mm}$; film $0.18 \mu \mathrm{m}$ ). The analytical conditions for fractionation of VFA were injection port temperature $250^{\circ} \mathrm{C}$, column temperature step up from 60 to $200^{\circ} \mathrm{C}$ in $7 \mathrm{~min}$ with a hold time of $10 \mathrm{~min}$ and the detector temperature was maintained at $300^{\circ} \mathrm{C}$ with $\mathrm{GC}$ grade air, hydrogen and nitrogen was used as carrier gas with a flow rate of $1.0 \mathrm{ml} / \mathrm{min}$. The samples were injected by an automatic injector at an injection volume of $1 \mu$ l using the split method and a 30:1 splitting ratio. Standard solutions of appropriate concentration $(\mathrm{mmol} / \mathrm{L})$ were prepared from the individual substances, namely acetic acid, propionic acid, iso-butyric acid, butyric acid, iso-valeric acid and valeric acid of analytical purity (Sigma-Aldrich) and the individual volatile fatty acids in the rumen liquor sample were identified based in the retention time of the standard. The concentrations of the individual VFA in the rumen liquor samples were determined by recording the area of both the VFA mixed standards and as well as the sample and expressed as $\mathrm{mmol} / \mathrm{L}$.

\section{Rumen HSP70 Gene expression}

The relative rumen HSP70 mRNA expression was carried out as per the protocol of Shilja et al (2015). Table 3 describes the primer sequences for HSP70 and the reference gene Glyceraldehyde 3-phosphate dehydrogenase (GAPDH). The relative expression of selected genes was studied using SYBR green chemistry (Maxima SYBR green qPCR master mix, Fermentas, USA). A $20 \mu \mathrm{L}$ reaction was carried out in duplicates using 50ng of template and $1 \mu \mathrm{M}$ primer concentrations. The RT $\mathrm{qPCR}$ reaction conditions were as follows: enzyme activation at $95^{\circ} \mathrm{C}$ for $10 \mathrm{~min}$ and amplification cycle ( 40 cycles; initial denaturation at $95^{\circ} \mathrm{C}$ for $15 \mathrm{sec}$, annealing at $60^{\circ} \mathrm{C}$ for $30 \mathrm{sec}$ and extension at $72^{\circ} \mathrm{C}$ for $30 \mathrm{sec}$ ). The melt curve analysis was performed to check the non-specific amplification. The GAPDH gene was used as an internal control and the relative expression was analyzed using the formula, ${ }^{-}{ }^{\Delta \Delta C T}$ (Tarif et al 2012). The results were expressed in fold change as compared to $\mathrm{C}$ group ( $\mathrm{C}=1$ fold $)$. 
Table 3 Primers used for HSP70 expression. GAPDH used as reference gene to normalize the gene expression of target genes.

\begin{tabular}{cccccc}
\hline Gene ID & Primers & Primer sequence (5”-3”) & $\begin{array}{c}\text { Primer } \\
\text { Length (bp) }\end{array}$ & $\begin{array}{c}\text { Product } \\
\text { Size (bp) }\end{array}$ & Accession No \\
\hline \multirow{2}{*}{ HSP70 } & $\mathrm{F}$ & TGGCTTTCACCGATACCGAG & 20 & 167 & NM_001285703.1 \\
& $\mathrm{R}$ & GTCGTTGATCACGCGGAAAG & 20 & & \\
GAPDH & $\mathrm{F}$ & GGTGATGCTGGTGCTGAGTA & 20 & 265 & $\underline{\text { AF030943 }}$ \\
& $\mathrm{R}$ & TCATAAGTCCCTCCACGATG & 20 & & \\
\hline
\end{tabular}

HSP70 - Heat Shock Protein 70; GAPDH - Glyceraldehyde 3-phosphate dehydrogenase

Histopathology

All the experimental bucks were sacrificed after 45 days of study. The representative rumen tissue samples of all the experimental bucks from different groups were collected immediately after slaughter from the same site and preserved in buffered $10 \%$ formalin solution. The fixed rumen tissue was processed routinely to get Haematoxylin and Eosin $(\mathrm{H}$ and E) stained sections (Luna 1968). The slides were interpreted in comparison with that of $\mathrm{C}$ group animals and representative lesions were photographed. Appropriate scores were allocated to histological changes. The scoring pattern for the histological section was followed as per method described by Gibson-Corley et al (2013). The scoring was given based on 0-3 point ( 0 -normal; 1 - mild; 2-moderate and 3 -severe changes) scale.

Statistical analysis

Repeated data for the variables studied were analyzed using general linear models (GLM) procedure by analysis of variance for repeated measurements which included the effects of thermal stress, nutritional stress and combined stress as well as their interactions. Effect of fixed factors, namely treatment (control, heat stress, nutritional stress and combined stress) and days (Time course effects of experiment were carried out on days $0,15,30$ and 45) on variables studied were analyzed. A post hoc analysis was performed using Duncan's multiple range tests for pairwise comparisons. The changes in the relative expression of rumen HSP70 mRNA in relation to GAPDH (Glyceraldehyde 3-phosphate dehydrogenase) as the housekeeping gene were analyzed by one-way analysis of variance (ANOVA) with Tukey's post-hoc analysis to compare the means between the groups. Results are shown as mean \pm SE from triplicates $(n=3)$. Rumen histological data were also analyzed by one-way analysis of variance (ANOVA) with Tukey's post-hoc analysis to compare the means between the groups. Data was presented as mean \pm
SEM and statistical analysis was carried out using SPSS software, version 15.0. The level of statistical significance was set at $\mathrm{p}<0.05$.

\section{Results}

Feed intake and body weight changes

The effects of heat, nutritional and combined stresses on feed intake were depicted in Figure 1. The feed intake on the basis of $\mathrm{g}$ DMI (dry matter intake) per kg metabolic body size per day differed significantly $(p<0.01)$ among the experimental groups. The feed intake was significantly ( $\mathrm{p}<$ 0.01) lower in both NS and CS group as compared to both C and HS groups. However feed intake did not differ between $\mathrm{C}$ and HS groups. The BW differed significantly $(\mathrm{p}<0.01)$ between ad libitum (C and HS) and restricted (NS and CS) feeding groups from week 2 onwards (Figure 2). Further, between $\mathrm{C}$ and HS groups the BW differed significantly ( $\mathrm{p}<$ 0.01) from week 4 onwards (Figure 2). Further, the experimental days and interaction between groups and experimental days significantly $(\mathrm{p}<0.01)$ influenced both FI and BW.

Rumen microbial enzyme activity

$\alpha$ - Amylase activity

The effect of HS, NS and CS on $\alpha$-amylase enzyme activity in the rumen liquor of goats is described in Table 4. The $\alpha$-Amylase EC, $\alpha$-Amylase IC and $\alpha$-Amylase total activities (TA) in the rumen liquor was similar across the different groups. However, the experimental days influenced all these parameters in the study. The experimental days significantly influenced $\alpha$-Amylase EC $(p<0.05)$, $\alpha$ Amylase IC $(\mathrm{p}<0.05)$ and $\alpha$-Amylase TA $(\mathrm{p}<0.01)$ in rumen liquor sample. In addition, there was significant $(\mathrm{p}<$ 0.01 ) interaction between groups and experimental days only for $\alpha$-Amylase IC activity in the study. 


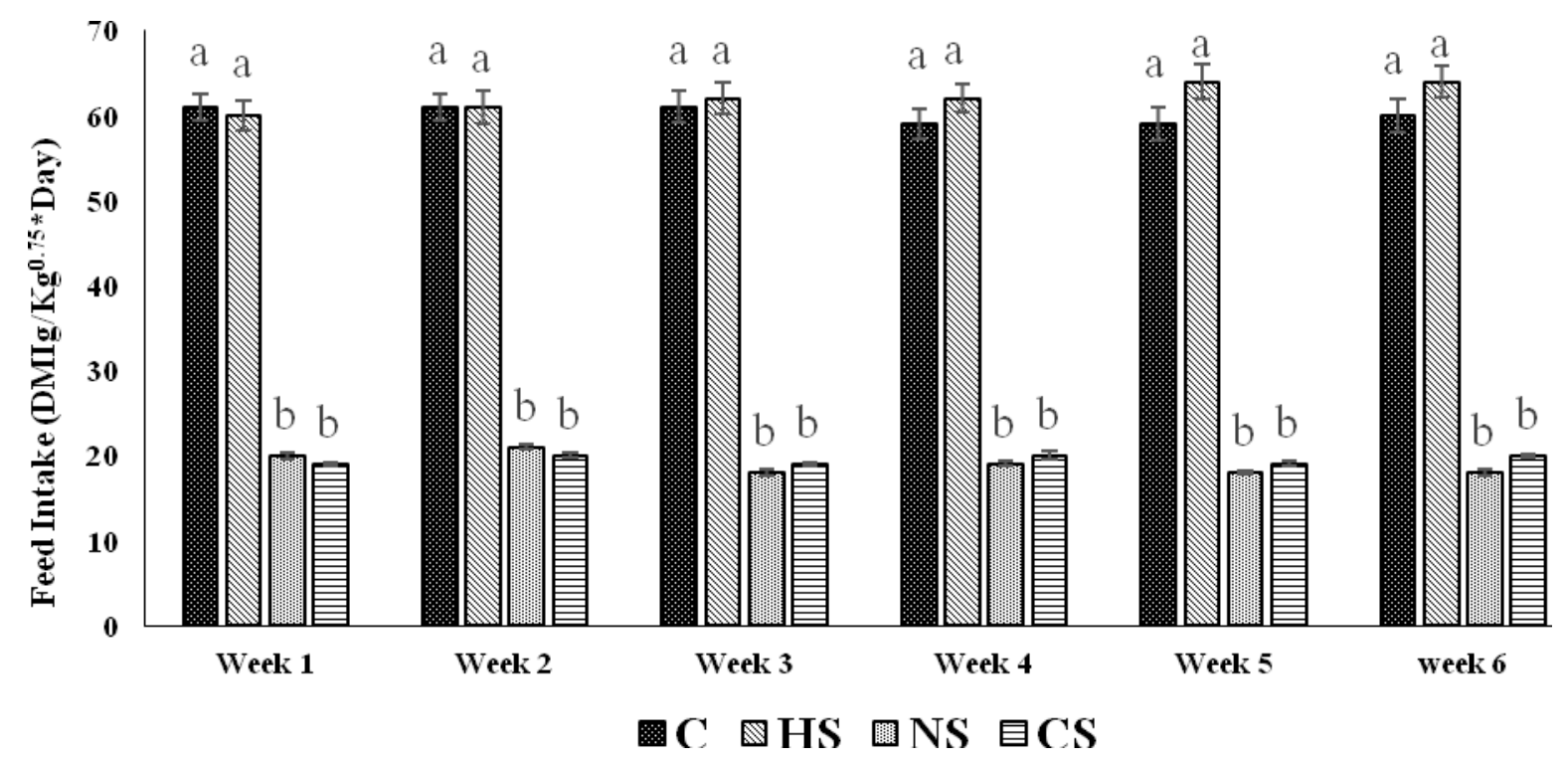

Figure 1 Feed intake changes between the control, heat stress, nutritional stress, combined stresses (heat \& nutritional) groups of goats. CControl; HS-Heat Stress; NS-Nutritional Stress; CS-Combined Stress. Values bearing different alphabets within a week differ significantly with each other at $\mathrm{p}<0.05$.

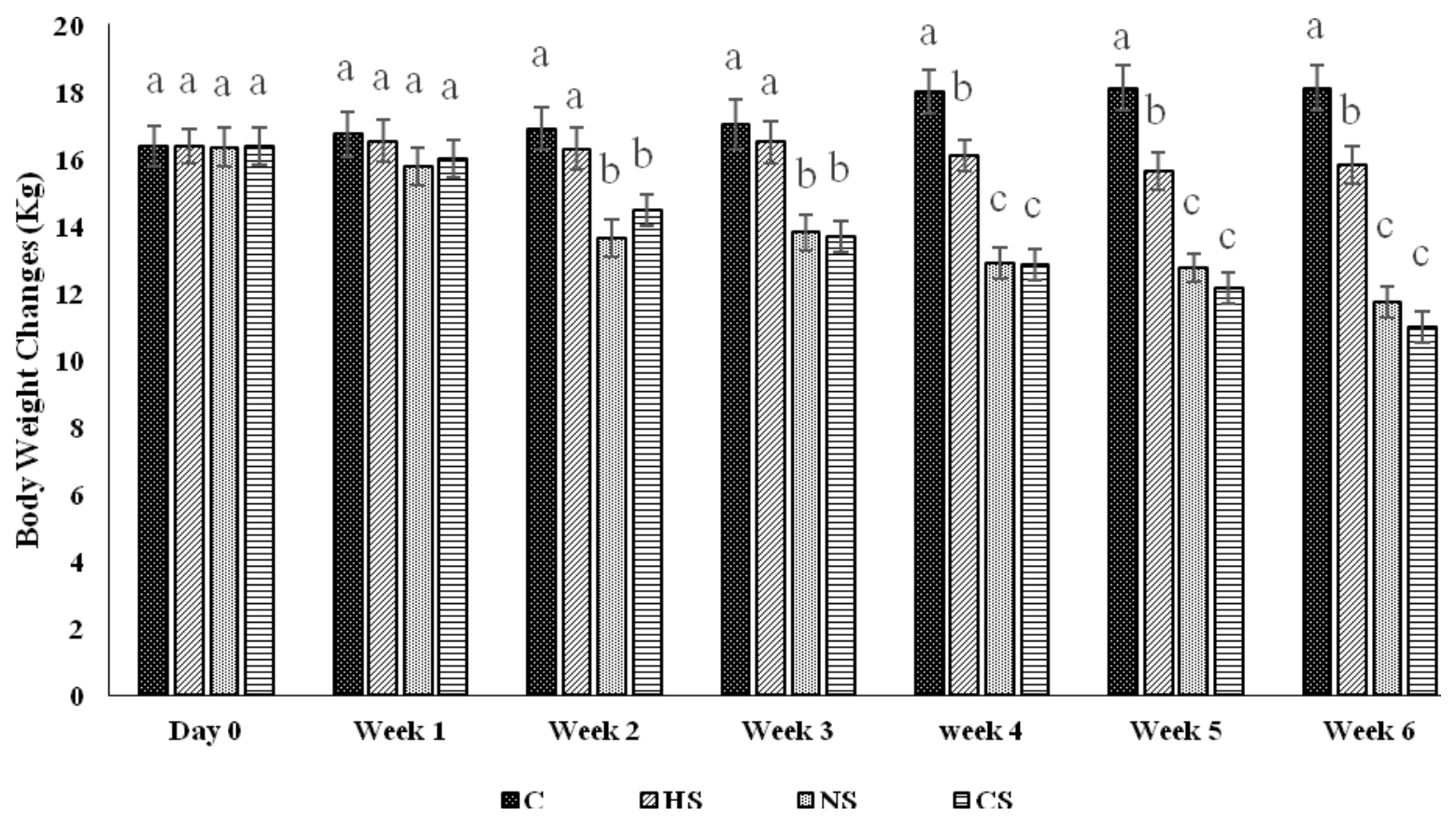

Figure 2 Body weight changes between the control, heat stress, nutritional stress, combined stresses (heat \& nutritional) groups of goats. CControl; HS-Heat Stress; NS-Nutritional Stress; CS-Combined Stress Values bearing different alphabets within a week differ significantly with each other at $\mathrm{p}<0.05$.

\section{CMCase activity}

The effect of HS, NS and CS on CMCase enzyme activity of rumen liquor is described in Table 5. The carboxy methyl cellulase EC, CMCase IC and CMCase TA in rumen liquor of bucks differed significantly $(\mathrm{p}<0.01)$ between the groups. Further, the experimental days significantly influenced the activities of CMCase EC, and CMCase TA in the rumen liquor during the study. In addition, there was significant $(\mathrm{p}<0.01)$ interaction between groups and experimental days only for CMCase EC activity in the rumen fluid sample of goats.

\section{Rumen fermentation metabolites}

The effects of HS, NS and CS on rumen fermentation metabolites are described in Table 6. Ammonia nitrogen in rumen liquor showed significant $(p<0.05)$ changes for the 
treatments. The highest $(\mathrm{p}<0.01)$ concentration of $\mathrm{NH}_{3}-\mathrm{N}$ was recorded in $\mathrm{C}$ while the lowest concentration was found in the CS group. However, its concentration was similar among the control, HS and NS groups without any significant effect. Further, experimental days significantly ( $p$ $<0.01$ ) influenced $\mathrm{NH}_{3}-\mathrm{N}$ throughout the study period. In addition, there was significant $(\mathrm{p}<0.05)$ interaction between groups and experimental days for the rumen liquor $\mathrm{NH}_{3}-\mathrm{N}$ in the study. The experimental treatments and days of collection had no influence on the rumen liquor $\mathrm{pH}$. However, the concentration of total $\mathrm{N}$ and TCA-ppt $\mathrm{N}$ was significantly higher ( $\mathrm{p}<0.01$ ) in ad libitum (C and HS) and lower in restricted feeding (NS and CS) groups. Further, experimental days also significantly $(\mathrm{p}<0.01)$ influenced total $\mathrm{N}$ and TCA-ppt. $\mathrm{N}$ in the study. In addition, significant ( $\mathrm{p}<0.01$ ) interaction was observed between groups and experimental days for total $\mathrm{N}$ and TCA-ppt. $\mathrm{N}$ in the study.

Table 4 Effect of heat stress, nutritional stress and combined stresses (heat and nutrition stress) on the $\alpha$-amylase enzyme activity in goats.

\begin{tabular}{|c|c|c|c|}
\hline FACTOR & $\begin{array}{c}\alpha \text {-Amylase EC } \\
(\mu \text { mol of } \\
\text { glucose } / \mathrm{ml} / \mathrm{hr})\end{array}$ & $\begin{array}{c}\alpha \text {-Amylase IC } \\
(\mu \text { mol of } \\
\text { glucose } / \mathrm{ml} / \mathrm{hr})\end{array}$ & $\begin{array}{c}\alpha \text {-Amylase TA } \\
(\mu \text { mol of } \\
\text { glucose } / \mathrm{ml} / \mathrm{hr})\end{array}$ \\
\hline$\mu \pm \mathrm{SE}$ & $69.59 \pm 6.60$ & $47.2 \pm 6.46$ & $116.78 \pm 11.32$ \\
\hline GROUP & ns & $\mathrm{ns}$ & $\mathrm{ns}$ \\
\hline $\begin{array}{l}\text { C } \\
\text { HS } \\
\text { NS } \\
\text { CS }\end{array}$ & $\begin{array}{l}77.17 \pm 11.49 \\
85.32 \pm 18.93 \\
60.71 \pm 09.66 \\
55.14 \pm 17.62\end{array}$ & $\begin{array}{l}50.28 \pm 9.23 \\
28.10 \pm 3.02 \\
58.09 \pm 14.0 \\
52.31 \pm 10.3\end{array}$ & $\begin{array}{l}127.45 \pm 22.15 \\
113.42 \pm 20.60 \\
118.80 \pm 27.43 \\
107.46 \pm 29.46\end{array}$ \\
\hline DAYS & $* *$ & $* *$ & $* *$ \\
\hline $\begin{array}{c}0 \\
45\end{array}$ & $\begin{array}{c}089 \pm 12.17 \\
50.16 \pm 5.60\end{array}$ & $\begin{array}{l}62.03 \pm 10.86 \\
32.36 \pm 04.55\end{array}$ & $\begin{array}{l}151.04 \pm 19 \\
82.53 \pm 9.5\end{array}$ \\
\hline GROUP $*$ DAYS & ns & $* *$ & $*$ \\
\hline
\end{tabular}

Volatile fatty acids

The effects of HS, NS and CS on the rumen liquor VFA profile are described in Table 7 . The concentration of acetate and iso-valerate was similar among the treatment groups. However, as the experiment progressed (days) their level was significantly $(\mathrm{p}<0.01)$ influenced. Further, interaction between groups and experimental days also did not significantly influence rumen liquor acetic acid level, but the concentration of iso-valerate was significantly influenced. Contrary to the rumen liquor acetate and isovalerate level, the propionate, butyrate and valerate concentration showed significant $(\mathrm{p}<0.01)$ changes for the experimental treatment. The propionate, butyrate and valerate concentration was higher $(\mathrm{p}<0.01)$ in ad libitum $(\mathrm{C}$ and HS) fed group and lowest in restricted feeding (NS and CS) groups. Further, the experimental days also significantly ( $\mathrm{p}<0.01$ ) influenced rumen propionate, butyrate and valerate level in the study. The concentration of propionate, butyrate and valerate in the rumen fluid was affected by treatment $\times$ days interaction $(\mathrm{p}<0.05)$. Rumen liquor Total volatile fatty acid (TVFA) level showed significant $(\mathrm{p}<$
0.05) changes in the treatment. Further, experimental days significantly $(\mathrm{p}<0.01)$ influenced the rumen liquor TVFA level in the study. Further, interaction between groups and experimental days also significantly $(\mathrm{p}<0.01)$ influenced the rumen liquor TVFA level in the study. The acetate: propionate $(\mathrm{A} / \mathrm{P})$ ratio was affected $(\mathrm{p}<0.01)$ by treatment and days of experiment. The ratio was narrower $(p<0.01)$ in ad libitum (C and $\mathrm{HS}$ ) and wider in restricted feeding (NS and CS) groups. Further, experimental days also significantly $(\mathrm{p}<0.01)$ influenced A/P ratio in the study. However, no interaction was found in the $\mathrm{A} / \mathrm{P}$ ratio between the groups and experimental days in the study.

\section{Rumen HSP70 expression}

Rumen HSP70 messenger ribo nucleic acid (mRNA) transcript expression between the C, HS, NS and CS groups of goats are described in Figure 3. The results revealed that rumen HSP70 mRNA expression was evident in C (1 fold), HS (1.23 fold), NS (0.34 fold) and CS (1.29 fold). On a comparative basis, the rumen HSP70 mRNA expression was significantly different only within the stress groups. The 
HSP70 mRNA expression was significantly $(\mathrm{p}<0.05)$ lower in the NS group as compared to both HS and CS group

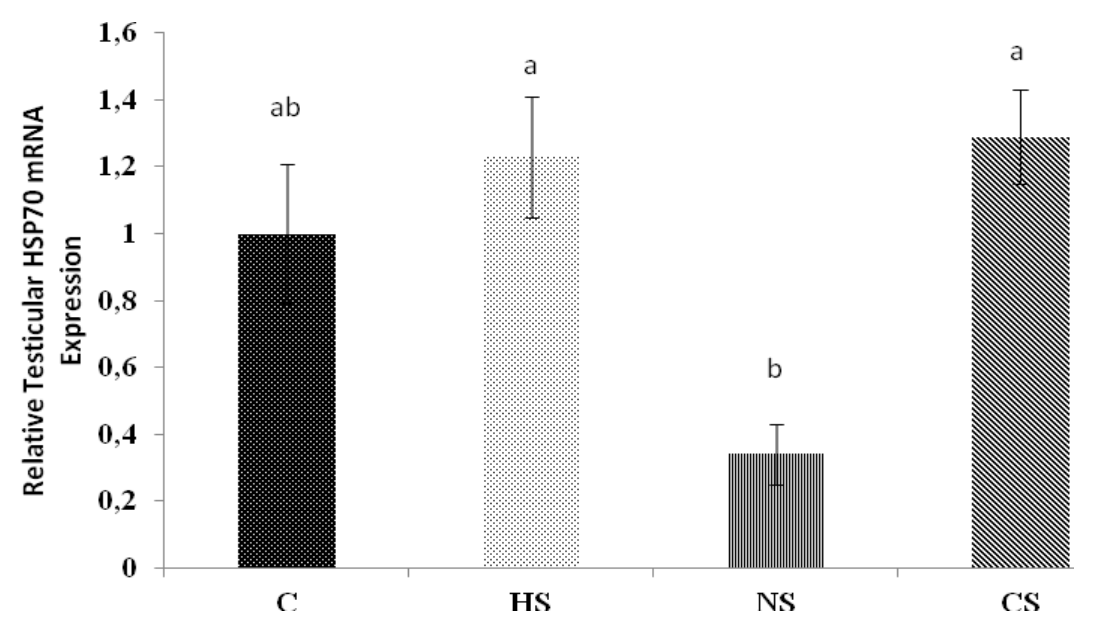

Figure 3 Rumen HSP70 mRNA transcript expression between the control, heat stress, nutritional stress, combined stresses (heat and nutritional) groups of goats. C-Control; HS-Heat Stress; NS-Nutritional Stress; CS-Combined Stress Values bearing different alphabets differ significantly with each other at $\mathrm{P}<0.05$.

Histopathology of Rumen

Figure 4 describes the $\mathrm{H}$ and $\mathrm{E}$ section of rumen in different group of animals. The rumen $\mathrm{H}$ and $\mathrm{E}$ section showed significant $(p<0.05)$ changes for different stresses. The length and thickness of rumen villi were significantly ( $p$
(Figure 3). However the HSP70 mRNA expression did not differ between C, HS and CS groups (Figure 3).

Table 5 Effect of Heat stress, Nutritional stress and combined stresses (Heat stress and Nutritional stress) on the Carboxy methyl cellulase activity in goats.

\begin{tabular}{|c|c|c|c|}
\hline FACTOR & $\begin{array}{l}\text { Carboxy methyl } \\
\text { cellulase EC } \\
(\mu \mathrm{mol} \text { of } \\
\text { glucose } / \mathrm{ml} / \mathrm{hr})\end{array}$ & $\begin{array}{c}\text { Carboxy methyl } \\
\text { cellulase IC } \\
(\mu \mathrm{mol} \text { of } \\
\text { glucose } / \mathrm{ml} / \mathrm{hr})\end{array}$ & $\begin{array}{c}\text { Carboxy methyl } \\
\text { cellulase TA } \\
(\mu \mathrm{mol} \text { of } \\
\text { glucose } / \mathrm{ml} / \mathrm{hr})\end{array}$ \\
\hline$\mu \pm \mathrm{SE}$ & $3.89 \pm 0.05$ & $4.52 \pm 0.11$ & $8.40 \pm 0.13$ \\
\hline GROUP & $* *$ & $* *$ & $* *$ \\
\hline $\mathrm{C}$ & $4.46^{\mathrm{a}} \pm 0.35$ & $5.11^{\mathrm{a}} \pm 0.31$ & $9.57^{\mathrm{a}} \pm 0.50$ \\
\hline HS & $3.99^{b} \pm 0.20$ & $5.23^{a} \pm 0.43$ & $9.23^{a} \pm 0.58$ \\
\hline NS & $3.44^{\mathrm{c}} \pm 0.08$ & $4.13^{b} \pm 0.29$ & $7.58^{\mathrm{b}} \pm 0.34$ \\
\hline $\mathrm{CS}$ & $3.66^{c} \pm 0.10$ & $3.59^{b} \pm 0.14$ & $7.25^{\mathrm{b}} \pm 0.18$ \\
\hline DAYS & $* *$ & Ns & $* *$ \\
\hline 0 & $4.36 \pm 0.11$ & $4.83 \pm 0.22$ & $9.20 \pm 0.27$ \\
\hline 45 & $3.41 \pm 0.11$ & $4.20 \pm 0.16$ & $7.62 \pm 0.18$ \\
\hline GROUP $*$ DAYS & $* *$ & Ns & Ns \\
\hline
\end{tabular}

EC-Extracellular activity; IC- Intracellular activity; TA- Total activity; C-Control; HS-Heat Stress;

NS-Nutritional Stress; CS-Combined Stress; $\mu$ - Overall Mean; SE- Standard error

**Indicates statistical significance at $p<0.01 ; *$ Indicates statistical significance at $p<0.05$; ns -Indicates non-significant; Values bearing different superscripts within a column differ significantly with each other

\section{Discussion}

Research pertaining to environmental stress influence on rumen fermentation pattern in livestock is very meager. In the changing climate scenario, these environmental stresses do not occur individually, but rather they occur simultaneously. Hence, research efforts are needed to study the cumulative impact of environmental stresses on rumen 
fermentation pattern. In that line, this experiment is an attempt to establish the cumulative impact of both HS and NS simultaneously on the goat rumen fermentation pattern. In the changing climatic condition, goat is considered to be an important species for the livelihood security of poor and marginal farmers. Hence the outcome of this research can add lots of value to the very limited existing knowledge available in this field. This in turn may pave way for development of suitable mitigation strategies to improve goat production in the changing climatic condition.

Feed intake of CS and NS was lower than the C and HS group throughout the study. In a similar study on Malpua sheep, Sejian et al (2010) and Maurya et al (2015) reported reduced feed intake in both NS and Cs groups. Depression of feed intake is a recognized physiological response of animals to heat stress (Marai et al 2007). Marai et al (2007) had postulated a reason for this reduced feed intake in sheep after thermal exposure. They explained that exposure of the animal to a high environmental temperature, stimulates the peripheral thermal receptors to transmit suppressive nerve impulses to the appetite center in the hypothalamus and thereby causing a decrease in feed intake. This decrease in feed intake could be an adaptive mechanism of goat to produce less body heat. The average BW of Osmanabadi bucks under heat, nutritional and combined stresses significantly decreased as compared to control group. Growth, the increase in the live body mass or cell multiplication, is controlled genetically and environmentally (Marai et al 2007). Elevated ambient temperature is considered to be one of the environmental factors negatively influencing average daily gain (Habeeb 1992). The reason for the effects of elevated ambient temperature on growth reduction could be due to decrease in anabolic activity and the increase in tissue catabolism (Marai et al 1999). The difference in BW between $\mathrm{C}$ and stress groups (HS, NS and CS) could be attributed to the reduction in their energy level in stress groups as the limited available energy could possibly have been used for the heat dissipation mechanism (Ocak et al 2009). The reduced BW recorded in CS group as compared to the HS group could be attributed to the cumulative effect of both heat and nutritional stress in CS bucks.

Table 6 Effect of heat stress, nutritional stress and combined stresses (heat and nutritional stress) on the biochemical parameter of rumen liquor in goats.

\begin{tabular}{|c|c|c|c|c|}
\hline FACTOR & $\begin{array}{c}\mathrm{NH}_{3} \mathrm{~N} \\
(\mathrm{mg} / 100 \mathrm{ml})\end{array}$ & $\mathrm{pH}$ & $\begin{array}{c}\text { TCA } \\
(\mathrm{mg} / 100 \mathrm{ml})\end{array}$ & $\begin{array}{c}\text { TOTAL NITROGEN } \\
(\mathrm{mg} / 100 \mathrm{ml})\end{array}$ \\
\hline$\mu \pm \mathrm{SE}$ & $27.59 \pm 1.15$ & $6.64 \pm 0.03$ & $124.24 \pm 5.19$ & $192.66 \pm 4.55$ \\
\hline GROUP & * & $\mathrm{Ns}$ & $* *$ & $* *$ \\
\hline $\mathrm{C}$ & $32.09^{a} \pm 1.47$ & $6.57^{\mathrm{a}} \pm 0.03$ & $158.79^{\mathrm{a}} \pm 8.44$ & $233.77^{\mathrm{a}} \pm 9.93$ \\
\hline $\begin{array}{l}\mathrm{HS} \\
\mathrm{NS} \\
\mathrm{CS}\end{array}$ & $\begin{array}{l}28.77^{\mathrm{ab}} \pm 1.72 \\
27.13^{\mathrm{ab}} \pm 1.10 \\
22.37^{\mathrm{b}} \pm 1.67\end{array}$ & $\begin{array}{l}6.58^{\mathrm{a}} \pm 0.11 \\
6.66^{\mathrm{a}} \pm 0.05 \\
6.74^{\mathrm{a}} \pm 0.07\end{array}$ & $\begin{array}{l}140.11^{a} \pm 11.4 \\
100.17^{b} \pm 10.4 \\
97.89^{b} \pm 12.44\end{array}$ & $\begin{array}{l}212.32^{\mathrm{a}} \pm 9.99 \\
163.34^{\mathrm{b}} \pm 10.9 \\
161.20^{\mathrm{b}} \pm 13.1\end{array}$ \\
\hline DAYS & $* *$ & ns & $* *$ & $* *$ \\
\hline $\begin{array}{c}0 \\
15 \\
30 \\
45\end{array}$ & $\begin{array}{l}31.29 \pm 1.32 \\
26.21 \pm 1.61 \\
27.99 \pm 1.40 \\
24.88 \pm 1.61\end{array}$ & $\begin{array}{l}6.59 \pm 0.04 \\
6.45 \pm 0.06 \\
6.77 \pm 0.11 \\
6.74 \pm 0.07\end{array}$ & $\begin{array}{l}171.80 \pm 8.0 \\
124.03 \pm 6.7 \\
93.88 \pm 8.98 \\
107.25 \pm 8.1\end{array}$ & $\begin{array}{l}242.37 \pm 8.59 \\
180.22 \pm 6.32 \\
165.37 \pm 8.29 \\
182.67 \pm 8.42\end{array}$ \\
\hline GROUP * DAYS & $*$ & $\mathrm{~ns}$ & $* *$ & $* *$ \\
\hline
\end{tabular}

The activities of $\alpha$-amylase showed no definite trend to both HS and NS in the study. The treatment did not influence both the extracellular and intracellular $\alpha$-amylase activities. Further, the TA of $\alpha$-amylase of rumen liquor also did not differ between the groups. This indicated that neither HS nor NS was able to influence starch degrading microbes and thus $\alpha$-amylase activities. However, as the experiment progressed $\alpha$-amylase activities in all the fractions (EC, IC and TA) were lowered which suggested a decrease in the population of starch degrading rumen microbes.

Lower CMCase activity in both the EC and IC fractions indicated that both NS and CS influenced cellulose digestibility by lowering the population of cellulose degrading microbes. A higher activity of the enzyme in the control group of animals suggests that moderate heat stress does not significantly influence cellulose degrading microorganism as well its enzyme activity. The significantly 
lower EC CMCase activity in CS groups in comparison to the HS group may be attributed to the additional nutritional stress in the CS group. Saro et al (2014) also reported the significant influence of quality of nutrition on CMCase activity in sheep. They reported that the animal with low quality feed had significantly lower CMCase activity in sheep as compared to high quality feed in sheep. The significant influence of experimental days and interaction between treatment and experimental days suggests that the animals were trying to adapt to the existing stressful condition to alter the extracellular CMCase activity in goat. Significantly lower activity of CMCase (both IC and total activity) in the rumen fluid in both the NS and CS groups as compared to ad libitum fed groups ( $\mathrm{C}$ and $\mathrm{HS}$ ) show the sensitivity of CMCase activities for the environmental stresses. Both HS and NS could have reduced the number of microorganisms residing in the rumen. The reduced CMCase activities could be due to lower protozoa concentration in the rumen in stressed animals. There are reports suggesting lower CMCase activities in defaunated animals (Santra and Karim 2002; Eugene et al 2004; Wina et al 2006). The nonsignificant interaction between treatment and experimental days suggests that the effect of treatment on IC and TA of CMCase persisted over the time. This shows that IC and TA of CMCase may be a reliable indicator for both HS and NS in goats.
$\mathrm{C}$
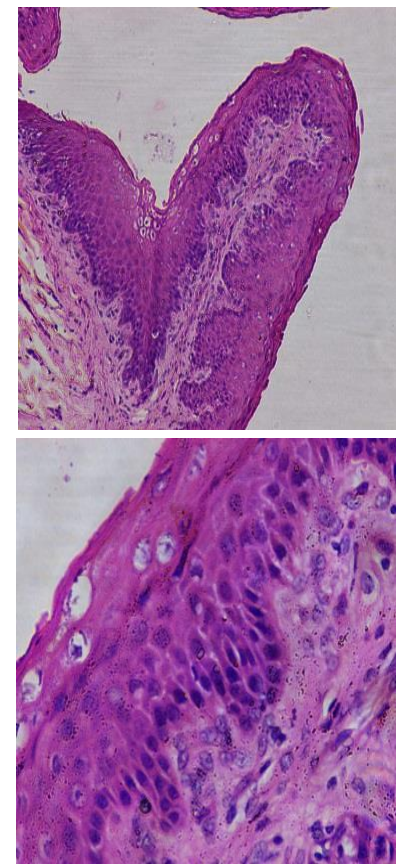

HS
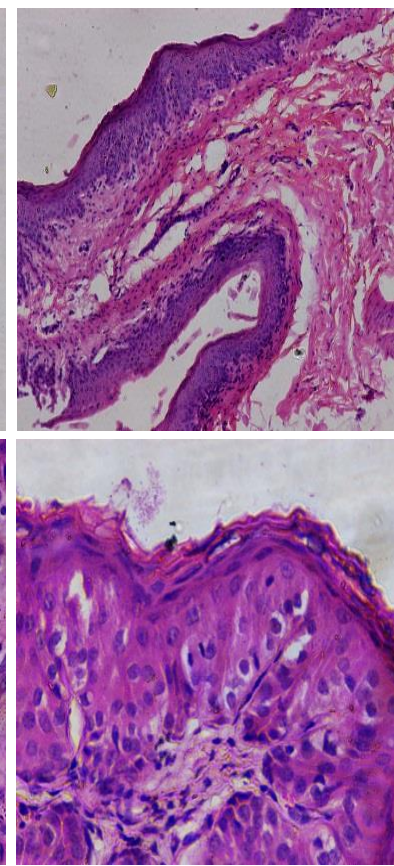

NS
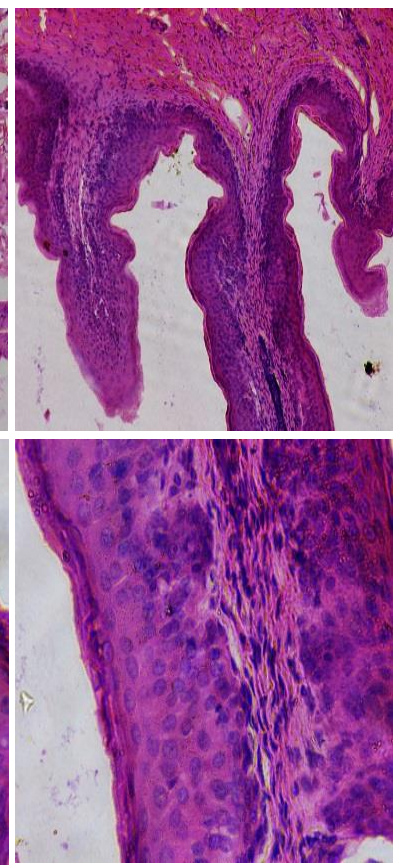

CS

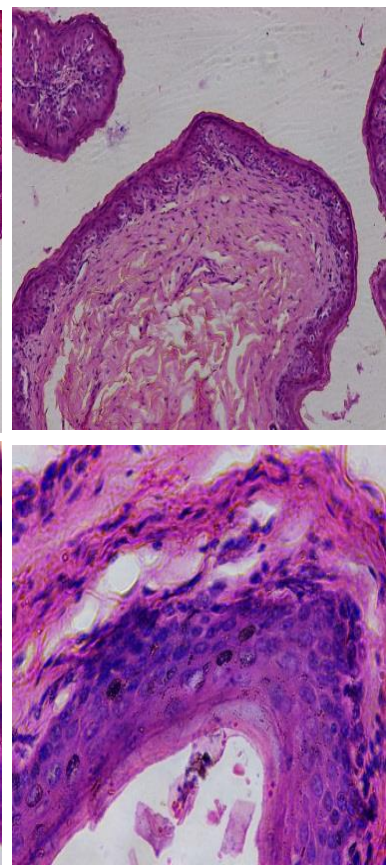

Figure 4 Rumen histopathological changes between the control, heat stress, nutritional stress, combined stresses (heat \& nutritional) groups of goats. Histopathological changes in H\&E stained sections from rumen of C (Control; $n=6$ ), HS (Heat Stress; $n=6$ ), NS (Nutritional Stress; $\mathrm{n}=6$ ) and CS (Combined stress; $\mathrm{n}=6$ ) animals subjected to different kinds of stress. The length and thickness of rumen villi were significantly $(\mathrm{P}<0.05)$ lower while keratinization was significantly $(\mathrm{P}<0.05)$ higher in stress groups $(\mathrm{HS}$, NS and CS) as compared to $\mathrm{C}$ group. Among the stress groups, the lowest $(\mathrm{P}<0.05)$ length and thickness of rumen villi and highest $(\mathrm{P}<0.05)$ keratinization was recorded in $\mathrm{CS}$ group as compared to HS and NS groups.

Beede and Collier (1986) observed that rumen function during HS may be altered by pituitary effects on basal metabolism such as reduced somatotropin and thyroid hormones. Both HS and NS independently did not influence rumen liquor $\mathrm{NH}_{3}-\mathrm{N}$. But the cumulative effect in CS group significantly reduced rumen liquor $\mathrm{NH}_{3}-\mathrm{N}$ concentration. The significantly lower $\mathrm{NH}_{3}-\mathrm{N}$ in $\mathrm{CS}$ group could be attributed to the joint impact of HS and NS. However, there are reports suggesting the influence of nutrition alone on the rumen ammonia concentration (Chanjula et al 2014). They reported that energy deficient diet significantly decreased rumen liquor $\mathrm{NH}_{3}-\mathrm{N}$ concentration. Rumen liquor $\mathrm{pH}$ has strong correlation with rumen microbial activity and rumen TVFAs production (Meng-zhi et al 2008). However, in the present experiment both HS and NS individually or in combination did not influence the rumen liquor $\mathrm{pH}$. But there are reports suggesting lower rumen liquor $\mathrm{pH}$ during $\mathrm{HS}$ in cattle (Kadzere et al 2002; Yadav et al 2012). Further, the non-significant influence of experimental days and interaction between treatment and experimental days suggests that the non-significant influence of these stresses on rumen liquor $\mathrm{pH}$ persisted over the time in the goat. 
Table 7 Effect of heat stress, nutritional stress and combined stresses (heat and nutritional stress) on volatile fatty acids production in goats.

\begin{tabular}{|c|c|c|c|c|c|c|c|}
\hline$\overline{\text { FACTOR }}$ & $\begin{array}{c}\mathrm{C} 2 \\
(\mathrm{mmol} / \mathrm{L})\end{array}$ & $\begin{array}{c}\mathrm{C} 3 \\
(\mathrm{mmol} / \mathrm{L})\end{array}$ & $\begin{array}{c}\mathrm{C} 4 \\
(\mathrm{mmol} / \mathrm{L})\end{array}$ & $\begin{array}{c}\mathrm{C} 5 \\
(\mathrm{mmol} / \mathrm{L})\end{array}$ & $\begin{array}{c}\mathrm{C} 5 \mathrm{i} \\
(\mathrm{mmol} / \mathrm{L})\end{array}$ & $\begin{array}{c}\text { TVFA } \\
(\mathrm{mmol} / \mathrm{L})\end{array}$ & $\begin{array}{c}\mathrm{C} 2: \mathrm{C} 3 \\
(\mathrm{mmol} / \mathrm{L})\end{array}$ \\
\hline$\mu \pm \mathrm{SE}$ & $54.367 \pm 1.58$ & $17.66 \pm 0.47$ & $7.93 \pm 0.29$ & $0.85 \pm 0.03$ & $0.817 \pm 0.04$ & $95.12 \pm 8.99$ & $3.3 \pm 0.09$ \\
\hline GROUP & ns & $* *$ & $* *$ & $* *$ & $\mathrm{~ns}$ & $*$ & $* *$ \\
\hline $\begin{array}{r}\mathrm{C} \\
\mathrm{HS} \\
\mathrm{NS} \\
\mathrm{CS}\end{array}$ & $\begin{array}{l}57.85 \pm 2.01 \\
56.03 \pm 2.17 \\
52.75 \pm 3.12 \\
50.84 \pm 3.17\end{array}$ & $\begin{array}{l}21.33^{\mathrm{a}} \pm 0.80 \\
20.21^{\mathrm{a}} \pm 1.14 \\
15.46^{\mathrm{b}} \pm 1.61 \\
13.65^{\mathrm{b}} \pm 1.13 \\
*^{*} *\end{array}$ & $\begin{array}{c}09.9^{\mathrm{a}} \pm 0.50 \\
9.93^{\mathrm{a}} \pm 0.54 \\
6.15^{\mathrm{b}} \pm 0.86 \\
5.76^{\mathrm{b}} \pm 0.78 \\
* *\end{array}$ & $\begin{array}{l}1.06^{\mathrm{a}} \pm 0.07 \\
0.91^{\mathrm{a}} \pm 0.08 \\
0.69^{\mathrm{b}} \pm 0.08 \\
0.67^{\mathrm{b}} \pm 0.09\end{array}$ & $\begin{array}{c}0.73 \pm 0.10 \\
0.81 \pm 0.08 \\
0.87 \pm 0.10 \\
0.86 \pm 0.12\end{array}$ & $\begin{array}{c}108.80^{\mathrm{a}} \pm 9.03 \\
109.11^{\mathrm{a}} \pm 9.56 \\
90.89^{\mathrm{a}} \pm 08.72 \\
71.69^{\mathrm{b}} \pm 07.12\end{array}$ & $\begin{array}{c}2.76^{\mathrm{b}} \pm 0.12 \\
2.89^{\mathrm{b}} \pm 0.15 \\
3.70^{\mathrm{a}} \pm 0.18 \\
3.85^{\mathrm{a}} \pm 0.20 \\
* *\end{array}$ \\
\hline DAYS & $* *$ & $* *$ & $* *$ & $* *$ & $* *$ & $* *$ & $* *$ \\
\hline $\begin{array}{c}0 \\
15 \\
30 \\
45\end{array}$ & $\begin{array}{l}60.76 \pm 1.73 \\
55.47 \pm 3.21 \\
52.43 \pm 2.60 \\
48.81 \pm 1.58\end{array}$ & $\begin{array}{l}22.99 \pm 1.03 \\
16.43 \pm 0.94 \\
16.82 \pm 0.88 \\
14.41 \pm 0.76\end{array}$ & $\begin{array}{l}10.7 \pm 0.52 \\
7.26 \pm 0.36 \\
6.50 \pm 0.55 \\
7.28 \pm 0.45\end{array}$ & $\begin{array}{l}1.26 \pm 0.05 \\
0.79 \pm 0.03 \\
0.57 \pm 0.06 \\
0.80 \pm 0.06\end{array}$ & $\begin{array}{l}1.32 \pm 0.11 \\
0.75 \pm 0.08 \\
0.45 \pm 0.04 \\
0.75 \pm 0.06\end{array}$ & $\begin{array}{l}112.9 \pm 10.7 \\
93.14 \pm 8.48 \\
89.59 \pm 8.75 \\
84.90 \pm 9.13\end{array}$ & $\begin{array}{l}2.72 \pm 0.11 \\
3.65 \pm 0.19 \\
3.28 \pm 0.12 \\
3.55 \pm 0.13\end{array}$ \\
\hline GROUP*DAYS & ns & $*$ & $* *$ & $* *$ & $* *$ & $* *$ & $\mathrm{~ns}$ \\
\hline
\end{tabular}

\footnotetext{
C2- Acetic acid; C3- Propionic acid; C4- Butyric acid; C5- Valeric acid; C5i- Iso Valeric acid; TVFA- Total volatile fatty acid; C:P- Acetate : Propionate ratio; C-Control; HS-Heat Stress; NS-Nutritional Stress; CS-Combined Stress; $\mu$ - Overall Mean; SE- Standard Error

$* *$ Indicates statistical significance at $\mathrm{p}<0.01 ; *$ Indicates statistical significance at $\mathrm{p}<0.05$; ns - Indicates non-significant; Values bearing different
}

The treatments in the study significantly influenced the production of propionic acid, butyric acid and valeric acid. However, HS alone did not significantly influence the different VFA production. Kadzere et al (2002) observed that HS reduced the concentration of VFA in the rumen of cattle and attributed this reduction to low feed intake heat stressed animals (Kadzere et al 2002). The similar effect of HS reducing TVFA production was also reported by other researchers in cattle (Tajima et al 2007; Nonaka et al 2008). The non-significant influence of HS on VFA production could be attributed to the lower magnitude HS in the current study. However, there are also reports indicating that ruminal temperature did not affect the proportion of VFA in cattle (King et al 2011; Yadav et al 2013). Further, there are also reports that HS brings about reduction in TVFA production by increasing the $\mathrm{pH}$ of rumen liquor (Hall 2009; Yadav et al 2013). Few authors have reported that changes in rumen fermentation pattern also may be brought about by changes in DMI (Smith et al 2013; Yadav et al 2013). However, when HS was combined with NS in CS group, it significantly reduced the TVFA production. This shows the severity of combined stress on VFA production. This difference in TVFA in CS group could be attributed to the influence of both HS and NS on the type of microbial population residing in the rumen (Uyeno et al 2010). Further, the significant interaction between treatment and experimental days on VFAs production showed that the relationship between the groups for the different VFAs production changed over time indicating that the animals are trying to adapt to the existing conditions. The wider acetate: propionate ratio in both NS and CS groups again indicates the sensitivity of nutrition in inducing changes in rumen fermentation pattern. However, Nonaka et al (2008) contradicted our finding and reported that the ratio of acetate to propionate decreased during HS.
This difference could be due to severe nutritional deprivation in NS and CS groups in the current study.

HSP70 is one of the most abundant and best characterized HSP family that consists of highly conserved stress proteins, expressed in response to stress, and plays crucial roles in environmental stress tolerance and adaptation in goat (Banergee et al 2014; Mohanarao et al 2014). The expression of rumen HSP70 mRNA expression in NS group was down regulated as compared to HS and CS groups. This shows the less severity of nutritional stress in inducing HSP70 expression as compared to heat stress. There are reports suggesting expression of HSP in the rumen (Cronje 2005). Cronje (2005) attributed this HSP expression in the rumen to redistribution of blood to the periphery and compensatory reduction in the blood supply to the gut, which damages cells lining the gut, permitting endotoxin to enter the body. These consequences are more severe in CS group since the rumen is populated with bacteria that are predominantly of the endotoxin-producing gram-negative type and since two stresses are impacting simultaneously the CS group, the endotoxin production would be more in this group leading to more HSP70 expression (Cronje 2005) as compared to NS group. The higher expression of HSP70 mRNA in CS group as compared to NS group indicates different adaptive mechanisms when the animals were subjected to two stresses simultaneously. Although CS groups also was subjected to nutritional stress still the level of HSP70 expression was higher, indicating the higher requirement for HSP70 to counter two stresses in the CS group. The significant changes in histological section of rumen in all stress groups show that in goat environmental stresses influences rumen to bring about changes in fermentation pattern. The reduced length and thickness and higher keratinization of rumen villi in CS group rumen 
indicate the severity simultaneous effects of two stresses in these goats. In addition, the higher expression of rumen HSP70 mRNA also supports this notion in CS goats.

\section{Conclusions}

The present study reveals that bucks subjected to HS and NS separately had less detrimental effects on buck's feed intake, BW changes and rumen fermentation pattern. Further, when compared to NS, HS had a less significant effect on the rumen fermentation pattern in the bucks. This indicates that when nutrition is not a limiting factor then bucks were able to better cope up with HS. However, when both these stresses were coupled, it had serious consequences on feed intake, BW changes and rumen fermentation pattern. Further, the study indicated that Osmanabadi bucks possessed the capability to adapt to the detrimental effects of environmental stresses which is evident from the significant interaction of treatment and experimental days on $\alpha$-amylase IC, $\alpha$-amylase TA, EC CMCase, $\mathrm{NH}_{3}-\mathrm{N}, \mathrm{TCA}$, total nitrogen, propionic acid, butyric acid, valeric acid, isovaleric acid, and TVFA. These attempts of establishing the impact of two stresses simultaneously is first of its kind in the goat and the outcome of this study in the goat may be useful in understanding the combined stress effect on rumen fermentation pattern in other livestock species. Further studies are required though to have a clear understanding of these associations at a mechanistic level if we are to fully exploit the potential of nutritionally manipulated rumen fermentation in bucks under HS condition.

\section{Conflict of Interest Statement}

The authors declare that there is no any conflict of interest for this manuscript

\section{Acknowledgements}

The authors are more grateful to Indian Council of Agricultural Research for funding this project and to the Director of the Institute for providing the research facilities. The authors are also thankful to P. A. Abdul Niyas and Shilja Shaji was their valuable help during the experiment.

\section{References}

Agarwal N, Agarwal I, Kamra DN, Chaudhary LC (2000) Diurnal variations in the activities of hydrolytic enzymes in different fractions of rumen liqu or of Murrah buffalo. Journal of Applied Animal Research 18:73-80.

[AOAC] Association of Official Analytical Chemists (1988) Official Methods of Analysis, $16^{\text {th }}$ edn., Association of Official Analytical Chemists, Washington, DC.
Banerjee D, Upadhyay RC, Chaudhary UB, Kumar R, Singh S, Ashutosh GJM, Polley S, Mukherjee A, Das TK, De S (2014). Seasonal variation in expression pattern of genes under HSP70: Seasonal variation in expression pattern of genes under HSP70 family in heat- and cold-adapted goats (Capra hircus). Cell Stress and Chaperones 19:401-408.

Beede DK, Coller RJ (1986) Potential nutritional strategies for intensively managed cattle during thermal stress. Jornal of Animal Science 62: 543-554.

Chanjula P, Pakdeechanuan P, Wattanasit S (2014) Effects of dietary crude glycerin supplementation on nutrient digestibility, ruminal fermentation, blood metabolites, and nitrogen balance of goats. Asian Australasian Journal of Animal Science 27:365-376.

Collier RJ, Beede DK, Thatcher WW, Israel LA, Wilcox CJ (1982) Influences of environment and its modification on dairy animal health and production. Journal of Dairy Science 65:2213-2227.

Cronje PB (2005) Heat stress in livestock - the role of the gut in its aetiology and a potential role for betaine in its alleviation. Recent Advances in Animal Nutrition in Australia 15:107- 122.

Eugene M, Archimede H, Michalet B, Fonty G (2004) Effects of defaunation on microbial activities in the rumen of rams consuming a mixed diet (fresh Digitaria decumbens grass and concentrate). Animal Research 53:187-200.

Gibson-Corley KN, Olivier AK, Meyerholz DK (2013) Principles for valid histopathologic scoring in research. Veterinary Pathology doi:10.1177/0300985813485099

Habeeb AA, Marai IFM, Kamal TH (1992) Heat stress. In: Philips, C., Piggens, D. (eds.), Farm Animals and the Environment. C.A.B. International 27-47.

Hall MB (2009) Heat Stress Alters Ruminal Fermentation and Digesta Characteristics, and Behavior in Lactating Dairy Cattle In: Chilliard Y, Glasser F, Faulconnier Y, Bocquier F, Veissier I, Doreau, M. (Eds), Proceeding of 11th International Symposium on Ruminant Physiology. Wageningen Academic Publication, Wageningen, The Netherlands, p. 204.

Herrero M, Havlík P, Valin H, Notenbaert A, Rufino MC, Thornton PK, Blümmel M, Weiss F, Grace D, Obersteiner M (2013) Biomass use, production, feed efficiencies, and greenhouse gas emissions from global livestock systems In: Clark, W.C. (Ed.), Proceedings of the National Academy of Sciences, 24 December 2013, USA, pp. 20888-20893.

Kadzere CT, Murphy MR, Silanikove N, Maltz E (2002) Heat stress in lactating dairy cows: a review. Livestock Production Science 77:59-91.

King CC, Dschaak CM, Eun JS, Fellner V, Young AJ (2011) Quantitative analysis of microbial fermentation under normal or high ruminal temperature in continuous cultures. The Professional Animal Scientist 27:319-327.

Luna LG (1968) Manual of histologic staining methods of the armed forces institute of pathology ( $3^{\text {rd }}$ Ed.). McGraw-Hill Book Company, New York, p 258.

Marai IFM, Habeeb AAM, Farghaly HM (1999) Productive, Physiological and Biochemical Changes in Imported and Locally Born Friesian and Holstein Lactating Cows under Hot Summer Conditions of Egypt. Tropical Animal Health and Production 31:233-243. 
Marai IFM, El-Darawany AA, Fadiel A, Abdel-Hafez MAM (2007) Physiological traits as affected by heat stress in sheep - A review. Small Ruminant Research 71:1-12.

Maurya VP, Sejian V, Kumar D, Naqvi SMK (2015) Impact of heat stress, nutritional restriction and combined stresses (heat and nutritional) on growth and reproductive performance of Malpura rams under semi-arid tropical environment. Journal of Animal Physiology and Animal Nutrition DOI: 10.1111/jpn.12443.

McDowell RE. 1972. Improvement of livestock production in warm climate. WH Freeman and Co, San Fransisco, USA.

Meng-zhi WANG, Hong-rong WANG, Heng-chun CAO, GuoXiang LI, Jie ZHANG (2008) Effects of Limiting Amino Acids on Rumen Fermentation and Microbial Community In vitro. Agricultural Sciences in China 7:1524-1531.

Miller GL (1959) Modified DNS method for reducing sugars. Anal Chem 31:426-428.

Mohanarao GJ, Mukherjee A, Banerjee D, Gohain M, Dass G, Brahma B, Datta TK, Upadhyay RC, De S (2014) HSP70 family genes and HSP27 expression in response to heat and cold stress in vitro in peripheral blood mononuclear cells of goat (Capra hircus). Small Ruminant Research 116:94-99.

Naqvi SMK, Sejian V (2010) Physiological adaptation of sheep to hot environmental conditions with special reference to climate change. In: Karim, S.A., Joshi, A., Sankhyan, S.K., Shinde, A.K., Shakyawar, D.B., Naqvi, S.M.K., Tripathi, B.N. (Eds.), Climate change and stress management: Sheep and goat production, ( ${ }^{\mathrm{st}} \mathrm{Ed}$.). Satish serial publishing house, Delhi, pp. 259-282.

Nonaka I, Takusari N, Tajima K, Suzuki Higuchi T, Kurihara KM (2008) Effects of high environmental temperatures on physiological and nutritional status of pre pubertal Holstein heifers. Livestock Science 113:14-23.

Ocak S, Darcan N, Cankaya S, Inal TC (2009) Physiological and biochemical responses in German fawn kids subjected to cooling treatments under Mediterranean climatic conditions. Turkish Journal of Veterinary and Animal Sciences 33:455- 461.

Riaz MQ, Sudekum KH, Clauss M Jayanegara A (2014) Voluntary feed intake and digestibility of four domestic ruminant species as influenced by dietary constituents: A meta-analysis. Livestock Science 162:76-85.

Santra A, Karim SA (2002) Influence of ciliate protozoa on biochemical changes and hydrolytic enzyme profile in the rumen ecosystem. Journal of Applied Microbiology 92:801-811.

Saro C, Ranilla MJ, Tejido ML, Carro MD (2014) Influence of forage type in the diet of sheep on rumen microbiota and fermentation characteristics. Livestock Science 160:52-59.

Sejian V, Maurya VP, Naqvi SMK (2010) Adaptability and growth of Malpura ewes subjected to thermal and nutritional stress. Tropical Animal Health and Production 42:1763-1770.

Sejian V, Maurya VP, Naqvi SMK (2011) Effect of thermal, nutritional and combined (thermal and nutritional) stresses on growth and reproductive performance of Malpura ewes under semiarid tropical environment. Journal of Animal Physiology and Animal Nutrition 95:252-258.

Sejian V, Maurya VP, Kumar K, Naqvi SMK (2013) Effect of multiple stresses (thermal, nutritional and walking stress) on growth, physiological response, blood biochemical and endocrine responses in Malpura ewes under semi-arid tropical environment. Tropical Animal Health and Production 45:107-116.
Shilja S, Sejian V, Bagath M, Mech A, David CG, Kurien EK, Varma G, Bhatta R (2015) Adaptive capability as indicated by behavioral and physiological responses, plasma HSP70 level and PBMC HSP70 mRNA expression in Osmanabadi goats subjected to combined (heat and nutritional) stressors. International Journal of Biometeorology DOI 10.1007/s00484-015-1124-5.

Smith DL, Smith T, Rude BJ, Ward SH (2013) Comparison of the effects of heat stress on milk and component yields and somatic cell score in Holstein and Jersey cows. Journal of Dairy Science 96:3028-3033.

Tajima K, Nonaka I, Higuchi K, Takusari N, Kurihara M, Takenaka A, Aminov RI (2007) Influence of high temperature and humidity on rumen bacterial diversity in Holstein heifers. Anaerobe 13:57-64. Upton M (2004) The role of livestock in economic development and poverty reduction. Working Paper, FAO.

Uyeno Y, Sekiguchi Y, Tajima K, Takenaka A, Kurihara M, Kamagata Y (2010) An rRNA-based analysis for evaluating the effect of heat stress on the rumen microbial composition of Holstein heifers. Anaerobe 16:27-33.

Van Soest PJ, Robertson JB, Lewis BA (1991) Methods for dietary fiber, neutral detergent fiber, and nonstarch polysaccharides in relation to animal nutrition. Jornal of Dairy Science 74:3583-3597.

Weatherburn MW (1967) Phenol- hypochlorite reaction for determination of ammonia. Analytical Chemistry 39:971-974.

Wina E, Muetzel S, Becker K (2006) The dynamics of major fibrolytic microbes and enzyme activity in the rumen in response to short- and long-term feeding of Sapindus rarak saponins. Journal of Applied Microbiology 100:114-22.

Yadav B, Singh G, Verma AK, Dutta N, Sejian V (2013) Impact of heat stress on rumen functions. Veterinary World 6:992-996.

Yadav B, Singh G, Wankar A, Dutta N, Verma AK, Chaturvedi VB (2012) Effect of thermal stress on methane emission in crossbred cattle. In: Pattaniak, A.R. (Ed.), Proceedings of VIIIth Biennial Conference of ANAC and symposium on Animal Nutrition Research Strategies for Food Security. November 28-30, Bikaneer, Rajasthan pp. 138. 